\title{
Teachers' opinions on the use of L1 in EFL classes
}

\author{
Sevim Inal ${ }^{\mathrm{a}}$ (1D), Irmak Turhanlı ${ }^{\mathrm{b}}$ \\ ${ }^{a}$ Çanakkale Onsekiz Mart university, Anafartalar Campus, Çanakkale 17100, Turkey \\ ${ }^{b}$ Çanakkale Onsekiz Mart University, Anafartalar Campus, Çanakkale 17100, Turkey
}

\author{
APA Citation: \\ İnal, S., \& Turhanl1, I. (2019). Teachers' opinions on the use of L1 in EFL classes. Journal of Language and Linguistic Studies, 15(3), 861- \\ 875 . \\ Submission Date:..16./12/2018. \\ Acceptance Date:..02./09.2019
}

\begin{abstract}
The use of L1 in EFL classes has been a controversial topic. Therefore, this study investigates the attitudes of university teachers towards the use of L1 and seek their opinions regarding the purposes for which L1 should be used in English classes. A questionnaire of 27 items with a five-point likert-type scale was administered, followed by a face-to face semi-structured interview. Descriptive and content analysis methods were employed. The results show that the use of L1 in L2 classes has facilitating functions in L2 learning environment and teachers do not perceive L1 as a hindering factor at the early stages of English learning; they also believe that L1 should be used with low-proficiency level students when making students aware of the differences and similarities between L1 and L2, explaining new vocabulary, clarifying difficult concepts, solving disciplinary problems and teaching grammar. The teachers' overall attitude towards using L1 was found to be slightly negative in line with the results of the questionnaire yet contradicted with those of the interview. It could be concluded that judicious use of L1 is favoured by teachers.
\end{abstract}

(C) 2019 JLLS and the Authors - Published by JLLS.

Keywords: L1 use; English language; teachers; attitude; purpose

\section{Introduction}

Scholars' opinions on the use of first language (L1) during language learning and teaching have been affected by a number of pedagogical, linguistic, and ideological factors throughout the history of foreign language teaching. In the early years of the period, the main goal was to develop the learners' reading ability in the target language. Accordingly, scholars and teachers had positive attitudes towards L1 use and welcomed in language classrooms in parallel with what was proposed by the Grammar Translation Method (GTM) which was dominant at the time. As people had more opportunities to travel and migrate to other countries, it was a necessity for them to develop their speaking ability in the target language. Consequently, the Direct Method was developed as a reaction to the GTM and students' L1 was totally rejected. Thus, the attitudes of the theorists, researchers and teachers towards the students' L1 were generally negative. Accordingly, students' L1 was excluded from the process of foreign language learning for a long time. Yet, the main goals and needs of language learners changed over time and the

\footnotetext{
* Corresponding author. Tel.: +5422909860

E-mail address: seviminal65@gmail.com Canakkale Onsekiz Mart University
} 
use of L1 has become a matter of debate. The fundamental point is whether the teachers should follow the English-only policy prescription. In a nutshell, the English-only approach was dominant in the 20th century, yet it has lost its appeal over time as the bilingual approach that supports judicious use of L1 has regained its popularity recently, therefore the current study attempted to seek the employability of L1 in English classes and lift the lid off about why bilingual approach has revived and how teachers perceived the use of L1 in their classes. L1 is inseparable part of language teaching and therefore any study on the functions and limitations of L1 use will help to understand in which context L1 should be used and will specify the functions and limitations of it in the EFL classes.

\subsection{Literature review}

Scholars have displayed a mild manner towards the use of L1 as humanistic approaches to language learning have been popular recently. Some scholars such as, Tang (2002); Lasagabaster (2013); Auerbach (1993), Kavaliauskienè \& Kaminskienè (2007); Burden, (2001; 2000); Storch \& Aldosari (2010); Schweers, (1999) considered the use of L1 as beneficial in the English classes and they believe the use of L1 facilitates learning. However, to Krashen (1981), Cook (2001), Cianflone, (2009), Mahmoudi,\& Amirkhiz (2011), Macdonald (1993), L1 should be banned as the use of L1 is accepted to have a detrimental effect on L2 learning process.

Considering the controversial debates on the use of L1 in English classes that has diminished in importance recently and of how these opposing ideas are perceived by teachers in classrooms today are worth to consider. Because it is believed that these debates on the use of L1 will further practitioners' and teachers' understanding and their views on the issue could influence their classroom practices. The results of this study are believed to be a valuable contribution to the studies on the use of L1 to set up certain limitations on the use of L1 in teaching English and develop sort of situations/criteria where L1 might be necessary and used effectively and strategically for the teachers to follow. There are some studies that investigated teachers' opinions on the use of L1 in Turkey, namely, Taşkın (2011), Sarandi (2013), Kayaoğlu (2012), Kicır and Mahmutoğlu (2013) are the few researchers who contributed to the area through their studies which investigated the teachers' views on L1 use.

\subsection{Research questions}

1. What are the attitudes of the English language teachers towards the use of L1 in English classes?

2. What is the teachers' perspective on the purposes for which L1 should be used in English classes?

\subsection{Open-ended interview questions}

1. What is your opinion about using L1 in EFL classes?

2. What do you think would be a problem to you and your students if you use English exclusively in the EFL classes?

\subsection{Aim}

The study examines the EFL teachers' opinions on the use of L1 in English classes.

\subsection{Significance of study}

L2 learners consciously or subconsciously think in mother tongue and use L1 to facilitate L2 input and output and this is sometimes inevitable. So the learner's first language can facilitate the second language learning, therefore, total banishment of L1 is regarded as an inappropriate preference on the 
grounds that it has a detrimental effect on learners' identity. Because L1 is a tool to respect learners' identity and related with both its psychological and socio-cultural roles. How learners' L1 should be dealt with by teachers and students in language classrooms; how L1 could be used in a balanced way particularly (Atkinson, 1993) have therefore been an important area of discussion.

\section{Method}

A five-point Likert-type scale questionnaire and interview questions were used to clarify the opinions of the teachers concerning the use of L1 in English classes.

\subsection{Setting and Participants}

18 university teachers working in Turkey attended the study.

\subsubsection{Sample/Participants}

Table 1. Distribution of Teachers According to Gender, Age and Teaching Experience

\begin{tabular}{lll}
\hline & & N \\
\hline Gender & Female & 14 \\
Age & $30-39$ & 4 \\
& $40-49$ & 14 \\
& $50-59$ & 3 \\
Experience & $11-20$ & 15 \\
& $5-10$ & 2 \\
& 21 years or above & 1 \\
\hline
\end{tabular}

In Turkey, usually teaching is considered as a prestigious profession by the females and therefore the number of females is higher than males. 14 of the teachers were female and 4 of them male. 14 of the teachers were aged between 30-39 and 3 of them were aged between 4049. Merely, one of the teachers was aged between 50-59. Regarding English teaching experiences, 15 of them had experience between 11-20 years and 2 of them were experienced between 5-10 years and only one teacher had 21 years or above. 
Table 2. Distribution of the Teachers According to Education and Training they received abroad (N18)

\begin{tabular}{lcc}
\hline & Responses & N \\
\hline Education in an overseas country & No & 16 \\
Training abroad & Yes & 2 \\
& No & 11 \\
\hline
\end{tabular}

\subsection{Materials and Instrumentation}

A five-point Likert-scale questionnaire, including some personal information explained below, was administered. The questionnaire was adapted from Elmetwally's (2012) questionnaire. The original questionnaire that included 20 items was initially checked by three researchers of the area and some changes were made according to their feedback. The statements that were double questions in the original questionnaire were written as two different items and a few of the statements that were considered to be unnecessary were omitted. Additionally, the word "slightly agree" was used instead of the word "neutral" as one of the points of the questionnaire. A few statements were omitted and extra items were added in the personal information part. In addition, a certain number of extra statements used in the questionnaires of a variety of researchers were added. Kelilo's (2012) statements were used as the items 20 and 21. Additionally, the items 23 and 24 were formed based on K1cır and Mahmutoğlu's (2013) statements. Kayaoğlu's (2012) statements were used as the items 25 and 26 and lastly, the statement 22 was adopted from Jancova's (2010) questionnaire. The questionnaire included a total number of 27 items investigated the teachers' opinions on the use of L1. The questionnaire includes three parts; the first part included the objective of the study. In the second part, personal information such as gender, native language, other spoken languages, age, teaching experience, education and training abroad was provided. The third part contained five items that explored the teachers' attitudes towards the use of L1 and the fourth part consisted of 21 items that focused on the teachers' views concerning the purposes for which L1 should be used. One item that examined the teachers' overall view regarding how much L1 should be used in English classes was included in the last part. The questionnaire was administered in English and the reliability analysis indicated that the value was .920 (Cronbach $\alpha=.920$ ). The quantitative data collected through the questionnaire explained above were complemented with the qualitative data collected by means of the interviews conducted with $11 \mathrm{EFL}$ teachers. The interview contained an unstructured question and a structured question. The first question was prepared by the researchers and one of Kelilo' (2012) interview was used as the second question of the interview. The interview questions are as follows: IQ1. What is your opinion about using L1 in EFL classes? IQ2. What do you think would be a problem to you and your students if you use English exclusively in the EFL classes?

\subsection{Data collection procedures}

Initially, the necessary permission was obtained from Elmetwall, (2012) originally developing the questionnaire, and an official permission from the university to conduct the research. The collected data were prepared for the analysis. 11 of the teachers working at the same school were also interviewed. At 
the beginning of interview, it was stated that the data to be collected through the interview would only be used for research purposes and each teacher was asked which language they would prefer to use while responding to the interview questions. 10 of the interviews were conducted in English and 1 of them in L1. The interviews were audio recorded making use of a mobile phone recorder and transcribed for the analysis. The quantitative data collected through the questionnaire were fed into a computer through Statistical Package for Social Sciences (SPSS). The items 3,4 and 5 of the questionnaire were different than the other items in that negative meaning related with the use of L1 was presented by them. Thus, the teachers' responses to these three items needed to be reversed in the relevant stage to obtain a reliable and valid result on the overall attitude of the teachers regarding the use of L1. Then, the data were analyzed by means of descriptive statistics to find out the mean values, standard deviation, frequency and percentage of the statements. The teachers' responses of strongly disagree and disagree revealed as frequency and percentages were gathered together and presented in the tables. The same way was followed for the teachers' responses of agree and strongly agree. Additionally, the frequency and percentage of the teachers' responses of agree and strongly agree to the items 3,4 and 5 mentioned above were displayed as the frequency and percentage of the teachers' responses of disagree and strongly disagree in the output. Thus, the results of strongly agree and agree and the results of strongly disagree and disagree were reversed and put into the table as the statements were written in the original negative versions in the table. Lastly, the percentages of the items that aim to examine attitudes of teachers presented in the relevant table were fed into the computer through Microsoft Excel and the chart that displayed the teachers' overall attitude towards the use of L1 was formed. After the interviews were transcribed, the one that was conducted in L1 was translated to English. The qualitative data collected through this data collection tool were analyzed by means of content analysis. As the first stage of the content analysis, codes that were found based on the research questions and the literature related with the use of L1 were listed and categorized under the relevant main themes. The main themes were the teachers' attitudes towards L1 use and their beliefs regarding the purposes for which L1 should be used. Next, the coding was tested on two sample data sets. The responses of the teachers that were repeated several times and considered to be important by the interviewee or that were found to be astonishing for the researcher were selected and written opposite the suitable code or sub-themes. After that, the relevant responses of each interviewee were combined together under the appropriate subthemes. The emerged sub-themes were put in a descending order from the most to the least common and the percentages of the sub-themes were calculated and presented along with the main theme. These findings were compared with the findings obtained as a result of the analysis of the quantitative data collected through the questionnaire.

\section{Results and Discussion}


Table 3. The Teachers' Attitudes towards the Use of L1 $(\mathrm{N}=18)$

Statements

Statements
Frequency and Percentage

Strongly disagree Slightly agree Agree
+St. Ag.

3.Using L1 prevents students

from learning Eng.

$9(50 \%) \quad 4(22.2 \%) \quad 5(27.8 \%)$

M

SD

5.I do not feel comfortable when

my students use their first language

$6(33.3 \%) \quad 4(22.2 \%) \quad 8(44.4 \%)$

$3.00 \quad 1.08$

4.Teachers should follow an English-

only policy in the classroom

$6(33.4 \%) 7(38.9 \%) \quad 5(27.8 \%)$

$3.00 \quad 1.08$

2. Students' first language should be

allowed during English lessons

$7(38.9 \%) \quad 6(33.3 \%) \quad 5(27.8 \%)$

$2.83 \quad .924$

1.Teachers should use students'first

language in Eng. classes

$7(38.9 \%) \quad 7(38.9 \%) \quad 4(22.3 \%)$

$2.78 \quad 1.06$

The table above illustrates that half of the teachers (50\%) disagreed or strongly disagreed that using L1 prevents students from learning English. Approximately $39 \%$ of the teachers slightly agreed with the view that the English-only policy should be applied by teachers in the classroom, which reveals that they do not have a totally decisive opinion on item $4.44 .4 \%$ of the teachers also agreed or strongly agreed that they did not feel comfortable when their students use L1 in English classes. Approximately $39 \%$ of the teachers did not agree that learners' L1 should be allowed during English lessons. Additionally, approximately $39 \%$ of the teachers disagreed or strongly disagreed that learners' L1 should be used by teachers.

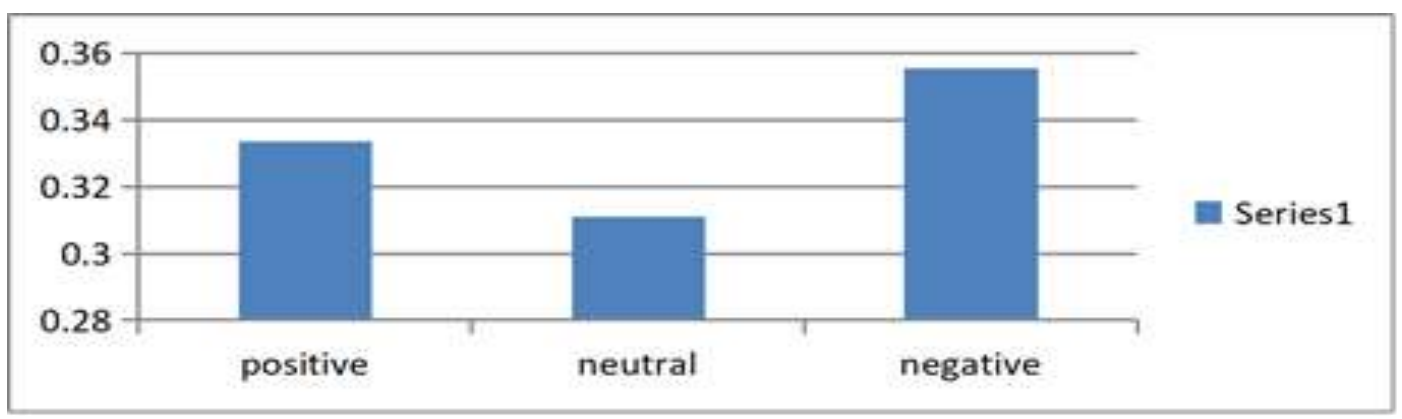

Figure 1. The teachers' overall attitude towards the use of L1 in English classes $(\mathrm{N}=18)$ 
The responses in the above figure were categorized as positive referring to strongly agree/agree; negative referring to strongly disagree/disagree and neutral. According to this, the teachers showed higher negative attitude towards the use of L1 than those who showed positive attitude. Additionally, $31 \%$ of the teachers showed neutral attitude. The data were also analyzed to find out the teachers' overall attitude towards the frequency of using L1 in English classes. $50 \%$ of the teachers believed that learners' L1 should sometimes be used and none of the teachers thought that L1 should never or always be used in the English classroom. Additionally, $38.9 \%$ of the teachers believed that L1 should rarely be used in English classes. Lastly, $5.6 \%$ of the teachers showed that L1 should often be used in the classroom.

Table 4. Teachers' Opinions about the Purposes for Which L1 Should be Used $(\mathrm{N}=18)$

Statements

Frequency and Percentage

Strongly disagree Slightly agree Agree

$\mathbf{M}$

SD

+ +Disagree $\quad+$ St. Ag.

8.It is appropriate to use $\mathrm{L} 1$ to raise

students' awareness of the

$1(5.6 \%) \quad 3(16.7 \%) \quad 14(77.8 \%)$

$4.00 \quad .840$

differences between L1 and English.

9. It is appropriate to use L1

to raise students'

$2(11.1 \%) \quad 3(16.7 \%) \quad 13(72.2 \%)$

3.89

.963

awareness of the similarities

between L1 and English.

10. It is appropriate to use L1 to explain new $2(11.2 \%) \quad 4(22.2 \%) 2(66.6 \%) \quad 3.83 \quad 1.15$

vocabulary especially abstract items.

6. It is appropriate to use

$\begin{array}{lllll}\text { L1 to explain difficult } & 2(11.1 \%) & 4(22.2 \%) & 12(66.7 \%) & 3.83\end{array} .985$

concepts.

22. It is appropriate to use 


\begin{tabular}{|c|c|c|c|c|c|}
\hline L1 to solve disciplinary problems & $3(16.7 \%)$ & $7(38.9 \%)$ & $8(44.4 \%)$ & 3.50 & 1.04 \\
\hline \multicolumn{6}{|l|}{ 7. It is appropriate to use $\mathrm{L} 1$ to } \\
\hline introduce new grammar rules. & $4(22.2 \%)$ & $5(27.8 \%)$ & $9(50 \%)$ & 3.44 & 1.04 \\
\hline \multicolumn{6}{|l|}{ 16. It is appropriate to use $\mathrm{L} 1$ to } \\
\hline express students' ideas when & $2(11.1 \%)$ & $9(50 \%)$ & $7(38.9 \%)$ & 3.33 & .767 \\
\hline \multicolumn{6}{|l|}{ they fail to do that in English. } \\
\hline \multicolumn{6}{|l|}{ 15. It is appropriate to use } \\
\hline L1 to express students' & $3(16.7 \%)$ & $8(44.4 \%)$ & $7(38.9 \%)$ & 3.33 & .907 \\
\hline
\end{tabular}

feelings when they fail to do that in English.

17. It is appropriate to use

L1 to explain English idioms.

$4(22.2 \%) \quad 7(38.9 \%) \quad 7(38.9 \%) \quad 3.22 \quad .878$

21. It is appropriate to use

L1 to elicit language

$7(38.9 \%) \quad 5(27.8 \%) \quad 6(33.3 \%)$

$3.00 \quad 1.13$

(e.g. How do we say ... in English?.

11. It is appropriate to use

L1 to help students

$7(38.9 \%) \quad 5(27.8 \%) \quad 6(33.3 \%) \quad 2.89 \quad .963$

feel more comfortable.

20. It is appropriate to use L1 to check

comprehension of the students in the class

$9(50 \%) \quad 5(27.8 \%) \quad 4(22.3 \%)$

$2.83 \quad 1.20$

14. It is appropriate to use $\mathrm{L} 1$ to

build up a good rapport with students

$8(44.5 \%) \quad 4(22.2 \%) \quad 6(33.3 \%) \quad 2.83$

12. It is appropriate to use $\mathrm{L} 1$ to

help students feel more confident.

$8(44.5 \%) \quad 5(27.8 \%) \quad 5(27.8 \%)$

$2.78 \quad .943$ 
13. It is appropriate to use

L1 to give instructions.

$5(27.8 \%)$

$4(22.3 \%)$

$2.67 \quad 1.08$

19. It is appropriate to use $\mathrm{L} 1$ to

complete small-group work activities.

$12(66.7 \%) \quad 4(22.2 \%)$

$2(11.2 \%)$

$2.39 \quad 979$

23. It is appropriate to use L1 to

explain the content of a reading text.

$11(61.1 \%)$

$5(27.8 \%)$

$2(11.1 \%)$

18. It is appropriate to use L1 to

complete pair work activities.

$12(66.7 \%)$

$4(22.2 \%)$

$2(11.2 \%)$

$2.33 \quad 1.02$

26. It is appropriate to use

L1 for writing course.

$11(61.1 \%) \quad 6(33.3 \%) \quad 1(5.6 \%)$ .878

24. It is appropriate to use L1 to

explain what is said in a listening passage.

$13(72.2 \%)$

$3(16.7 \%)$

$2(11.1 \%)$

2.11

.963

25. It is appropriate to use

L1 for speaking course.

$15(83.4 \%)$

$2(11.1 \%)$

$1(5.6 \%)$

1.67

.907

As displayed above, the majority of the teachers (77.8\%) thought that L1 should be used to raise students' awareness of the differences between L1 and L2 and $72.2 \%$ of the teachers believed in appropriateness of using L1 to raise students' awareness of the similarities between L1 and English languages. $66.6 \%$ of the teachers believe that $\mathrm{L} 1$ should be used to explain new vocabulary, particularly abstract items. $66.7 \%$ of the teachers agreed or strongly agreed that it was suitable to use L1 to explain difficult concepts. $44.4 \%$ of the instructors believed in appropriateness of using L1 for the purpose of solving disciplinary problems. Half of the teachers $(50 \%)$ agreed that it was appropriate to use L1 to introduce grammar rules. Half of the teachers $(50 \%)$ slightly agreed that it was appropriate for students to use L1 when they fail to express themselves in English. Similarly, $44.4 \%$ of the teachers slightly agreed that L2 learners should use L1 to express their feelings if they cannot do it English. Approximately $39 \%$ of the teachers slightly agreed that L1 should be used to explain English idioms, while nearly $39 \%$ of the teachers agreed or strongly agreed with the relevant view. Approximately 39 $\%$ of the teachers disagreed or strongly disagreed with the idea that it was appropriate to use L1 to elicit language. Similarly, nearly $39 \%$ of the teachers disagreed or strongly disagreed with appropriateness of using L1 to help students feel more comfortable. Additionally, half of the teachers (50\%) thought that it was inappropriate to use L1 to check comprehension of the students. $44.5 \%$ of the teachers did not agree that L1 should be used to build up a good rapport with students. Similarly, $44.5 \%$ of the teachers did not believe in appropriateness of using L1 to help students feel more confident. Half of the 
teachers (50\%) thought that L1 shouldn't be used to give instruction. $66.7 \%$ of the teachers disagreed or strongly disagreed with the opinion that it was appropriate to use L1 to complete small-group work activities. $61.1 \%$ of the teachers thought that it was not appropriate to use L1 to explain the content of a reading text. Additionally, $66.7 \%$ of the teachers thought that L1 shouldn't be used to complete pair work activities. $61.1 \%$ of the teachers disagreed or strongly disagreed that it was appropriate to use L1 for writing course. Similarly, $72.2 \%$ of the teachers did not believe that L1 should be used for explaining what is said in a listening passage. The majority of the teachers $(83.4 \%)$ thought that L1 shouldn't be allowed in speaking course. The teachers believed that the use of L1 for the purposes of making students aware of the differences and similarities between L1 and English, explaining new vocabulary, clarifying difficult concepts, solving disciplinary problems and teaching grammar was more appropriate than making use of L1 for the purposes of completing small-group work and pair work activities.

\subsection{Findings of the Interviews}

This section reports the findings of the interviews. T with numbers in the table 5 refers to teacher and the number assigned for each teacher instead of their names.

Table 5. Percentages of the Teachers' Responses According to the Emerged Sub-themes

\section{The teachers' attitudes towards}

\section{the use of $\mathrm{L} 1$}

The use of L1 when it is needed T7, T8, T9, T10, T11

The use of L1 with lower level

students

General opinion regarding the use

of L1 (positive)

The exclusive use of English

(English-only) as an obstacle

for comprehension

The exclusive use of English

(English-only) as a

T1, T4, T8

3

27

psychologically detrimental factor

for students

Translation as a necessary

technique

T1, T4, T9

3

The exclusive use of English 


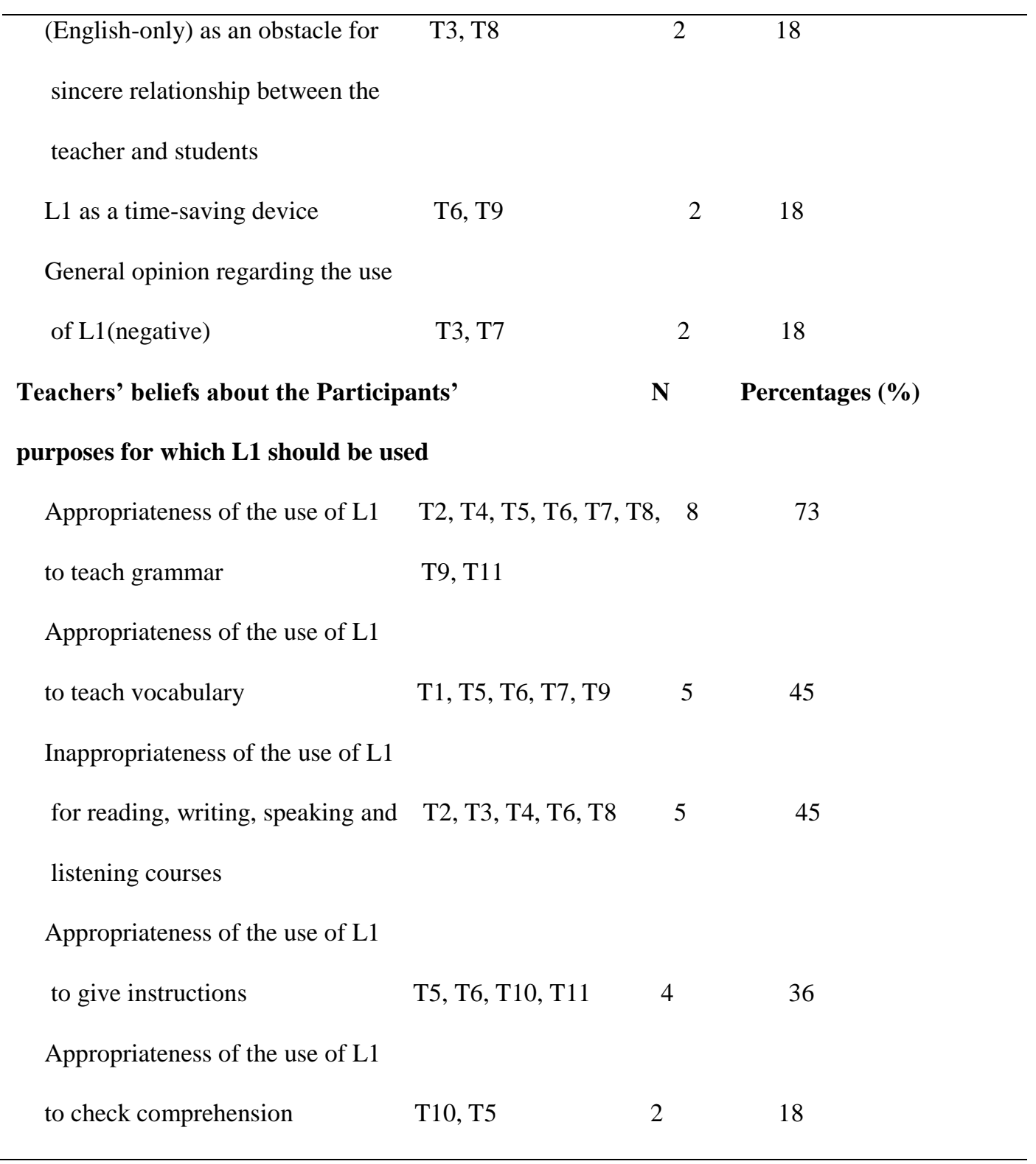

As demonstrated above, all of the teachers interviewed agreed that $\mathrm{L} 1$ is to be used when it is needed in the classroom. This result is supported by the analysis of the item 27 in the questionnaire which indicated that half of the teachers believed that learners' L1 should sometimes be used in the classroom and $38.9 \%$ of them thought that learners' L1 should rarely be used. One of the relevant responses of the teachers is as follows: Excerpt from T2:"When I see a need to explain something in L1, I do it, it's a positive approach. It depends on the student actually." More than half of the teachers (64 \%) believed that L1 should be used particularly with low level learners by emphasizing that the amount of L1 use should be decreased as learners progress. Another excerpt from the teachers(T3) is:"But actually, it depends on the level of the students. If you're working with low-level students, I think L1 should be a part of it. But if you are lucky and working with above B1 students, you can use English very easily in any class." Additionally, more than half of the teachers (64\%) in the interview and $34 \%$ of them through the questionnaire showed positive attitude towards the use of L1, whereas only 18 of them in the interview and $36 \%$ of them through the questionnaire showed negative attitude towards the use of L1. When the overall views are considered, it would not be wrong to say the positive tendency towards the use of L1 is higher than the negative tendency. Some of the statements of the teachers are as follows: T1- "I think (using L1 in classes) has positive aspects on students." T7- "My general attitude towards 
the use of L1 is negative. You have to speak English in the classroom, because as a teacher you are the source of information, so when you are speaking English, students take you as a model and they try to understand you." The responses to the second interview question (see the interview questions) were also categorized as the sub-themes under the main theme of the teachers' attitudes. The teachers' responses to the relevant question indicated, $45 \%$ of the teachers believed that the English-only approach could cause comprehension problems for students, which overlaps with the finding of the item 4 in the questionnaire with the mean value 3.00 ( $\mathrm{SD}=1.08)$. One of the responses is below: T6- "The student doesn't understand when we use only English and asks about it repeatedly." Additively, $27 \%$ of the teachers expressed that the exclusive use of English in the classroom could be psychologically detrimental for learners as it could cause stress or frustration when they are exposed to the English-only, particularly if they are beginners. One of the teachers stated as: T4- "When I use English in the classroom to take their attention, they are surprised at first and then they feel the pressure on them and don't want to listen to me anymore. They feel stressed." $18 \%$ of the teachers stated that the English-only could prevent them from developing a completely sincere relationship with the students. Another teacher expressed as: T3- "There is just one disadvantage to me, it's about the relationship between you and the students. You can't go deeper with them, so jokes become a bit limited, and life stories become a bit limited and most of the students do not want to communicate if they don't have to." Besides, translation is seen as a necessary and useful technique by some of the teachers (27\%) and lastly $18 \%$ of the teachers regarded L1 as a time-saving device. Some of the relevant responses are below: T1- "For some classes, I positively support translation." T9- "It is usually better to use L1 rather than trying to .... by using only L2, because it takes a lot of time and the classroom time is usually precious." The qualitative data were also analyzed to find out the teachers' opinions related with the purposes for which L1 should be used as the second main theme. Five sub-themes were emerged accordingly with the teachers' responses under the relevant main theme and initially the finding of the first sub-theme regarding the use of L1 to teach grammar is to be noted. As illustrated in Table 5, the majority of the teachers ( $73 \%)$ thought that L1 could be utilized to teach grammar and the analysis of the item 7 of the questionnaire is in the same direction with this finding with the mean value 3.44 ( $\mathrm{SD}=1.04)$. One of the excerpts is below: T11"While teaching grammar, it's useful for me. So I use it." $45 \%$ of the teachers were also in favor of the use L1 to teach lexical items, particularly the abstract ones. One of the statements is as follows: T9"Now, research also shows that mother tongue can be useful, especially to explain abstract concepts." Additionally, $45 \%$ of the teachers emphasized that it was inappropriate to use L1 to teach reading, writing, speaking and listening, which is supported by the analysis of the items 23, 24, 25 and 26 of the questionnaire indicating that the use of L1 in skill courses was considered to be inappropriate by the majority of the teachers with the mean value 2.05 ( $\mathrm{SD}=0.913$ ). One of the responses is: T2- "But I think in skill courses, L1 should not be used, because you also have body language and other materials." Besides, $36 \%$ of the teachers stated that $\mathrm{L} 1$ could be used to give instructions, particularly the complex ones, whereas $50 \%$ of the teachers disagreed with this idea $(\mathrm{M}=2.67, \mathrm{SD}=1.08$, see item 13 , the questionnaire). One of the teachers expressed as: T11- "It can be used while giving instructions if students can not understand." A small percentage of the teachers were in favor of the use of L1 to check comprehension and this is supported by the analysis of the item 20 in the questionnaire with the mean value $2.83(\mathrm{SD}=1.20)$.

\section{Discussion}

The teachers in the current study displayed a slightly negative overall attitude towards involvement of L1 in L2 classes; however, the qualitative data indicated that the teachers' general opinion about the use of L1 was positive. The relevant result of the current study does not match with the result of 
Elmetwally (2012) as his participants' general attitude towards utilizing L1 was found to be positive, which could be associated with the fact that the teachers in Elmetwally's study were high school teachers whereas the university instructors were involved in this study. Additionally, the finding of the current study relatively matches with the results of K1cır and Mahmutoğlu's (2013) and Sarandi's (2013) studies as certain amount of use of L1 was approved by the teachers in the related studies. Gaebler (2014), Alshammari (2011), Timor (2012), and the researcher of the current study found that the use of L1 for the purposes of explaining difficult points, teaching vocabulary and grammar was supported by the teachers. The findings of this study also match with Elmetwally's (2012), Kelilo's (2012) and Sarandi's (2013) studies in that the teachers were in favor of using L1 for explaining the differences and similarities between L1 and L2.

\section{Conclusions}

L1 was considered by the teachers as a facilitator of L2 learning environment; however, they did not approve of their own use of L1 in the classroom. Furthermore, the teachers' overall attitude towards the use of L1 was slightly negative and they believed that L1 should sometimes be used in the classroom. Although the teachers' attitude was found to be slightly negative according to the finding of the questionnaire, the result of the interviews demonstrated that the teachers' general opinion concerning the use of L1 was positive. The teachers believed that L1 facilitates L2 learning and has a various functions such as making students aware of the differences and similarities between L1 and English, explaining new vocabulary, clarifying difficult concepts, solving disciplinary problems and teaching grammar. Similarly, in the interview, the teachers expressed that using L1 for teaching grammar and vocabulary was appropriate, but it shouldn't be used in the process of developing the four skills.

\section{Implications}

Some conclusions can be drawn from this study which may be useful for the teachers and practitioners. The teachers in this study defined certain purposes and situations where L1 would be useful. Namely these are, to explain difficult concepts and grammar, to achieve and maintain classroom discipline and overcome disruptive behaviours, explain abstract concepts, create awareness of differences and similarities between L1 and L2. The teachers can try using L1 on these occasions found in this study and observe the effectiveness of them in L2 learning process.

\section{Recommendations}

Some of the findings in this study have also been verified by other researchers as well and overlapping the findings validate the current research pool however it would be useful if the findings of this study be compared with the results of some other relevant studies to support the existing research pool. Additionally, the relationship between the use of L1 in L2 production, the level of retention and achievement can be investigated. 


\section{References}

Alshammari, M. M. (2011). The use of the mother tongue in Saudi EFL classrooms. Journal of International Education Research, 7(4), 95-102.

Auerbach, E. 1993. Reexaming English only in the ESL classroom. TESOL Quarterly 27, 1, pp. 9-32.

Burden, P. (2001). When do native English speaking teachers and Japanese college students disagree about the use of Japanese in the English conversation classroom?, The Language Teacher Online, $25(4)$.

Burden, P. (2000). The use of the students mother tongue in monolingual English "conversation" classes at Japanese universities, The Language Teacher Online, 24(6).

Elmetwally, E. E. (2012). Students' and teachers' attitudes towards the use of learners' mother tongue in English language classrooms in UAE public high schools. The British University in Dubai, Dubai.

Gaebler, P. (2014). L1 use in FL classrooms: graduate students' and professors' perceptions of English use in foreign language courses. The CATESOL Journal, 25(1), 66-83.

Jancova, L. (2010). Translation and the role of the mother tongue in ELT. Palacky University Olomouc, Olomouc.

Kavaliauskienè, G. \& Kaminskienè, L. ( 2007). Translations as a learning tool in English for specific purposes, Kalbotyra, 57(3).

Kayaoğlu, M. N. (2012). The use of mother tongue in foreign language teaching from teachers' practice and perspective. Pamukkale Üniversitesi Eğitim Fakültesi Dergisi, 32(2), 25-35.

Kelilo, J. A. (2012). Exploring the use of first language in 'English focus' EFL classrooms: focus on Jimma teachers' college. Jimma University, Jimma. http://asian-efl-journal.com/wpcontent/uploads/mgm/downloads/69453700.pdf

Kıcır, Z., \& Mahmutoğlu, H. (2013). The use of mother tongue in EFL classrooms. EUL Journal of Social Sciences, 4(1), 49-72.

Lasagabaster, D. (2013). The use of the L1 in CLIL classes: The teachers' perspective. Latin American Journal of Content and Language Integrated Learning, 6(2), 1-21. doi:10.5294/lacli1.2013.6.2.1 eISSN 2322-9721.

Mahmoudi, L., \& Amirkhiz, S. (2011). The use of Persian in the EFL Classroom The case of English Teaching and Learning at pre-university level in Iran. English Language Learning Journal, 4, 135140

Sarandi, H. (2013). The use of L1 in English preparatory schools: where is the balance? Anthropologist, 16(1-2), 325-335.

Storch, N., \& Aldosari, A. (2010). Learners' use of first language (Arabic) in pair work in an EFL class. Language Teaching Research, 14, 355-375.

Tang, J. (2002). Using L1 in the English Classroom. January 2002, English Language Forum

Timor, T. (2012). Use of mother tongue in teaching a foreign language. Language Education in Asia, 3(1), 7-17. Advance online publication. doi:10.5746/LEIA/12/V3/I1/A02.

Turhanl1, I. (2018). The use of L1 as the mother tongue in EFL classrooms.MA Dissertation Çanakkale Onsekiz Mart University, Çanakkale. 


\section{Yabancı dil olarak İngilizce olarak öğretildiği sınıflarda öğretmenlerin anadil kullanımı üzerine görüşleri}

\section{$\ddot{O} \mathbf{z}$}

Yabancı dil olarak İngilizce'nin öğretildiği sınıflarda anadilin kullanılması günümüzda hala tartışılan bir konudur. $\mathrm{Bu}$ nedenle, mevcut çalışma, üniversitedeki öğretim elemanlarının İngilizce sınıflarında anadil kullanımına yönelik tutumlarını ve anadil kullanılacaksa hangi amaçlar için kullanılacağına ilişkin görüşlerini ortaya çıkarmayı amaçlamaktadır. Veriler, 27 soruluk beşli likert tipi ölçek ve iki açık uçlu görüşme yoluyla toplanmıştır. Veri analizinde, betimsel istatistik ve içerik analizi yöntemleri kullanılmıştır. Bulgular, anadilin ikinci dil öğrenme ortamında anlamayı kolaylaştırıcı bir rolü olduğunu ve öğretmenlerin, anadil kullanımını İngilizce öğrenmenin erken safhalarında engelleyici bir etmen olarak görmediklerini ortaya koymaktadır. Katılımcılar, başlangıç seviyesinde olan öğrencilere İngilizce öğretirken, anadil ve ikinci dil arasındaki benzerlikleri ve farklılıkları konusunda öğrencilerde farkındalık yaratmada, yeni sözcükleri öğretmede, zor kavramları açıklamada, sınıf içi disiplin sorunlarını cözmede, dilbilgisi öğretiminde anadilin kolaylaştırıcı etkisi olduğuna inanmaktadırlar. Anket sonuçlarına göre, öğretim elemanları anadil kullanımına yönelik tutumlarının kısmen olumsuz olduğu, fakat eldeki bu sonucun açık-uçlu sorulara verilen yanıtlarla tam olarak örtüşmemesine rağmen öğretim elemanları hangi durumlarda anadilin kullanılması gerektiğini belirtmiştir. Buna dayanarak, onların genel tutumlarının anadilin ihtiyaç duyulduğunda makul oranda kullanılması gerektiği yönünde olduğu söylenebilir.

Anahtar sözcükler: anadil kullanımı; İngilizce dil öğretimi; öğretmen; amaç; tutum

\section{AUTHOR BIODATA}

$1^{\text {st }}$ Author :

Sevim Inal did her PhD in English language teaching and has been teaching English since 1995. She published in various journals and attended national and international conferences.

$2^{\text {nd }}$ Author:

Irmak Turhal obtained her MA degree and has been teaching English to different age groups. 